\title{
Comparison of fruit tree richness and abundance as an indicator of food resource availability for the endangered Tauraco bannermani in Mount Oku and Mount Mbam, Western Highlands of Cameroon
}

\author{
Taku AWA II ${ }^{*}$ and Nobel Valery Kengne TALLA
}

\author{
University of Dschang, Faculty of Science, Laboratory of Applied Biology and Ecology, P. O. Box 67, \\ Dschang, West Region, Cameroon. \\ *Corresponding author; E-mail: takuawa@yahoo.co.uk ; Tel. +237 677454444
}

\begin{abstract}
The Endangered Bannerman's Turaco, Tauraco bannermani, is an arboreal montane forest bird, endemic to the Bamenda Highlands and currently facing several threats including selective extraction of trees, some of which are fruit trees on which the bird is known to feed. This study assessed the abundance and species richness of fruit trees known to provide food resources to the Bannerman's Turaco as a factor contributing to the variation in the population size of the bird between Mt Oku and Mt Mbam. 45 plots where systematically established at each site using the point transect method targeting suitable habitats of Bannerman's Turaco. In each plot, we identified and recorded all fruit trees known to provide food resources to Bannerman's Turaco. Diameter at breast height and height of each fruit tree were measured. Data was analysed using Chi-square tests at threshold probability of 5\%. Results obtained indicated that fruit trees were significantly more abundant in Mt Oku ( $\mathrm{n}=531)$ compared with Mt Mbam ( $\mathrm{n}=154)$ (Chisq = 207.49, df = 1 and $\mathrm{p}=0.0002)$. Mt Oku also had a significantly higher fruit tree biomass $($ Chisq $=5701$, df $=1$ and $\mathrm{p}<$ 0.0002). Similar results were obtained when we controlled for altitude between sites. Of the eight fruit tree species known to provide food resources to Bannerman's Turaco, we recorded seven at Mt Oku (Allophylus bullatus, Ficus sp, Maesa lanceolata, Podocarpus latifolius, Prunus africana, Schefflera abyssinica and Schefflera mannii) and five at Mt Mbam (Allophylus bullatus, Ficus sp, Prunus africana, Schefflera abyssinica and Schefflera mannii). These findings suggest that the significantly higher abundance and biomass of fruit trees contribute to explain the higher population size of Bannerman's Turaco in Mt Oku compared with Mt Mbam. Hence, conservation efforts to protect this endangered bird should take into consideration the protection of fruit trees on which it feeds.
\end{abstract}

(C) 2019 International Formulae Group. All rights reserved.

Keywords: Bannerman's Turaco, Frugivores, Fruit trees, Montane forest, IBAs.

\section{INTRODUCTION}

Various environmental variables (seasonal variations in rainfall and temperature, spatial and temporal microhabitat conditions, differences in forest stand structure, site productivity, vegetation composition, disturbance patterns, secondary biotic interactions and available land area) explain variations of animal species abundance (Rahbek, 2005; Gregory et al., 2009; Mengesha et al., 2011; Konan and Yaokokore-Beibro, 2015). Although these variables are constantly proposed as the causes in spatial variation of species abundance, no factor has yet been accepted as the primary determinant of these variations. 
While climate is considered as one if not the major driver of bird's abundance, species responses to climate are variable in both magnitude and rate (Walther et al., 2002).

Within the tropical forests are birds of different feeding guilds that contribute to ecosystem services and functions. The diversity and abundance of frugivorous birds depending completely or partly on fruits, seeds and flowers, constitute part of the high species richness and diversity of tropical rainforest (Moran et al., 2005), that is arguably by far the richest terrestrial ecosystem in the world (Joppa et al., 2011). Differences in richness of frugivorous species are generally explained by the abundance and diversity of their feeding resources (Fleming and Ranta, 2005). Williams and Middleton (2007) and Nirmala (2016) stated that variations in the abundance of a species' food resources also lead to variations in the abundance of the species. In plant-frugivore mutualism, birds are probably the most important agents of seed dispersal of native and woody plants, most likely because of their abundance, diversity and mobility (Bascompte and Jordano, 2007; Garcia et al., 2009).

Like animals, plant species richness and abundance are also affected by several factors. Precipitation and ambient energy are widely argued to be the main causes of species richness in vascular plants (Hawkins et al., 2003; Field et al., 2005). Tree growth and productivity, hence their survival is directly influenced by water availability, light and heat which are also essential for the physiological processes of the plants (Field et al., 2005). Species richness and diversity of plants is also highly accounted for by the dispersal of their seeds for which birds are probably the greatest dispersers of plant seeds, due to their high abundances (Bascompte and Jordan, 2007).

Bannerman's Turaco has been reported to feed on the fruits of Podocarpus milianjanus, Maesa lanceolata, Schefflera spp, Allophylus bullatus and Ficus spp and sometimes feeds on the leaves, buds and flowers of these trees (Dowsett-lemaire and Dowsett, 1993; Fishpool and Evans, 2001). Prunus africana is also another important fruit tree on which the Bannerman's Turaco relies for food resources (Cunningham and Mbenkum, 1993). The bird was also reported to feed on Podocarpus latifolius by an experienced local field guide during our pilot study.

Bannerman's Turaco is an arboreal frugivore of afromontane forest (Mckay, 1994), endemic to the Bamenda Highlands where Mt Mbam is considered the second stronghold for the species after Mt Oku (Mckay, 1994; Njabo and Languy, 2000). Even though fruits comprise the greatest portion of their diet, Turaco's in general, also rely partly on animal food like insects, especially when raising their young (Jarvis and Curie, 1978; Fry et al., 1988). It can survive in degraded forest so long as tall fruiting trees are present (Stuart, 1986). Bannerman's Turaco numbers about 2000 pairs at Mt Oku (Forboseh and Ikguingei, 2001) out of a total estimated population in the range of $2500-9999$ individuals (BirdLife International, 2017) with Mt Mbam considered to have the second highest population (Njabo and Languy, 2000). A survey by Njabo (2003) reported the bird in Mt Mbam as "observed more than once but not common" while a recent survey by Ngute et al. (2019) reported it as "common" (1-10 individuals may be seen or heard in suitable habitats daily). Forboseh and Ikfuingei (2001) reported an overall density of 0.18 birds/ha in montane forest habitats in Mt Oku (KilumIjim forest) with an average encounter rate of $3.73 \mathrm{birds} / \mathrm{km}$. Although no population size figures exist for Mt Mbam for a direct comparison, both sites are considered strongholds for Bannerman's Turaco in the Bamenda highlands with Mt Oku being the first (Njabo and Languy, 2000). According to Forboseh and Ikfuingei (2001) the population of Bannerman's Turaco is in decline based on impending threats such as forest clearance for agriculture, grazing (McKay and Coulthard, 1996), selective extraction of trees for firewood and timber, some of which are fruit trees on which the bird is known to feed. While there are several potential explanatory variables for the differences in species abundance between these sites, this research focuses on investigating the richness and abundance of fruit trees known to serve as 
food resources to the endangered Bannerman's Turaco as factors contributing to explain the variation in population size of the species between Mt Oku and Mt Mbam.

\section{MATERIALS AND METHODS Study area}

This study was carried out in Mount Oku and Mount Mbam, both of which are IBAs (Important Bird Areas) within the Bamenda Highlands that is part of the Cameroon mountain archipelago.

Mt Oku is the largest remnant of Central African cloudy forest (Asanga, 2002). It is protected as a community forest and has a Plant Life Sanctuary. It lies between $6^{\circ} 05^{\prime}$ $6^{\circ} 20^{\prime} \mathrm{N}$ and $10^{\circ} 20^{\prime}-10^{\circ} 34^{\prime} \mathrm{E}$. It spans an altitudinal range of $1600-3011 \mathrm{~m}$ and encloses an area of 17,323 ha, of which about half is montane forest. At its peak of $3011 \mathrm{~m}$, it represents the second highest peak in mainland West Africa (Asanga, 2002) after Mt Cameroon. The climate at Mt Oku is characterized by a long rainy season from mid-March to November followed by a short dry season from December to mid-March, with mean annual rainfall of about 2,334 mm (Forboseh and Ikfuingei, 2001). Mean temperature varies between 13 and $25{ }^{\circ} \mathrm{C}$. Geographically, Mt Oku spans in two administrative Divisions, Bui and Boyo, in the North West Region (Figure 1). There are about 20 villages around the forest of Mt Oku and the main socio-economic activities of the people are agriculture, livestock keeping, timber and wood exploitation for personal use.

Mt Mbam also known as the Mbam Hill Forest is an unprotected site that lies between latitude $5^{\circ} 54^{\prime}-6^{\circ} 10^{\prime} \mathrm{N}$ and longitude $10^{\circ} 40^{\prime}-10^{\circ} 46^{\prime} \mathrm{E}$ in the Noun Division of West Region of Cameroon (Figure 1). It spans an altitudinal range of about $1100-2335 \mathrm{~m}$ and encompasses a total surface area of 12,000 ha of which 3,000 ha is montane forest (Fotso et al., 2001). The rainy season stretches from April to mid-November with a mean annual rainfall of about 2,100 $\mathrm{mm}$ (Tye, 1986). The mean annual temperature varies between 21 and $23{ }^{\circ} \mathrm{C}$ (Kottek et al., 2006). With nomadic cattle grazers at the high altitudes, the main socio-economic activities within the c. 10 villages at the foot of the hills are agriculture, timber and wood exploitation, trading and hunting.

\section{Sampling design}

Sampling quadrats of $40 \times 40 \mathrm{~m}$ were located $100 \mathrm{~m}$ apart on alternate sides of preestablished transects, systematically chosen such that they cut across suitable habitats of Bannerman's Turaco from the foot of the mountain towards the top. Fieldwork was conducted from mid-June to mid-July 2017, with 45 plots sampled at each site.

\section{Data collection}

In each sampling plot, we recorded the coordinates and elevation at the center of the plot with a hand held GPS Garmin 64. All fruit tree species known to serve as food resource to Bannerman's Turaco were identified and recorded. With the aid of a laser range finder, we measured the height of each individual fruit tree species and measured its DBH (diameter at breast height) with a measuring tape. The DBH was considered at $1.2 \mathrm{~m}$ above ground level and when the tree was on a slope, the DBH was measured from the uphill side (Chapman et al., 1992). In cases where the tree had a buttress at the 1.2 $\mathrm{m}$ point, the DBH was considered just above the buttress.

At the end of the fieldwork, fruit tree specimens (leaves, flowers and fruits where applicable) were taken to the Cameroon National Herbarium in Yaoundé to confirm identification of tree species and an attestation of tree identification was obtained.

\section{Data analysis}

Chi-square test of independence was used to determine if there was a significant difference at a threshold probability of $5 \%$ between the categorical variables (site and species of fruit trees). Analyses were initially performed with overall data from the 45 sampling plots at each site after which repeat analysis were done with limited set of 36 plots per site having controlled for the altitudinal variations between sites. $\mathrm{R}$ software version 3.4.2 was used for analysis.

Species diversity was calculated using Shannon-Wiener Diversity Index $(H)$. This 
was done using the following Shannon diversity formula:

$H=-\sum p i \ln p i$

Where,

$P i=$ the proportion of individuals found in species $\mathrm{i}$, and calculated as $P i=\mathrm{ni} / \mathrm{N}$. Where $\mathrm{ni}$ is the number of individuals in species $\mathrm{i}$ and $\mathrm{N}$ is the total number of individuals in the community.

Sorenson's similarity index was calculated to show how similar the sites are in terms of species richness. This Sorenson's index was calculated as follows:

$\mathrm{CC}=2 \mathrm{C} / \mathrm{A}+\mathrm{B}$

Where,

$\mathrm{CC}=$ represents the Sorenson's index

$\mathrm{A}=$ number of species at $\mathrm{Mt} \mathrm{Oku}$
$\mathrm{B}=$ number of species at Mt Mbam

$\mathrm{C}=$ the number of species common to both sites.

Biomass of each fruit tree was computed (using their individual DBH and heights), based on allometric equations of Djomo et al. (2010).

$\mathrm{B}=\exp \left(-2.9946+0.9317 \ln \left(\mathrm{D}^{2} \mathrm{H}\right)\right)$

Where,

$\mathrm{B}=$ biomass

$\mathrm{D}=$ diameter at breast height

$\mathrm{H}=$ tree height

-2.9946 and $0.9317=$ are constants

Total biomass of each tree species was divided by the total surface area sampled to obtain the biomass per hectare.

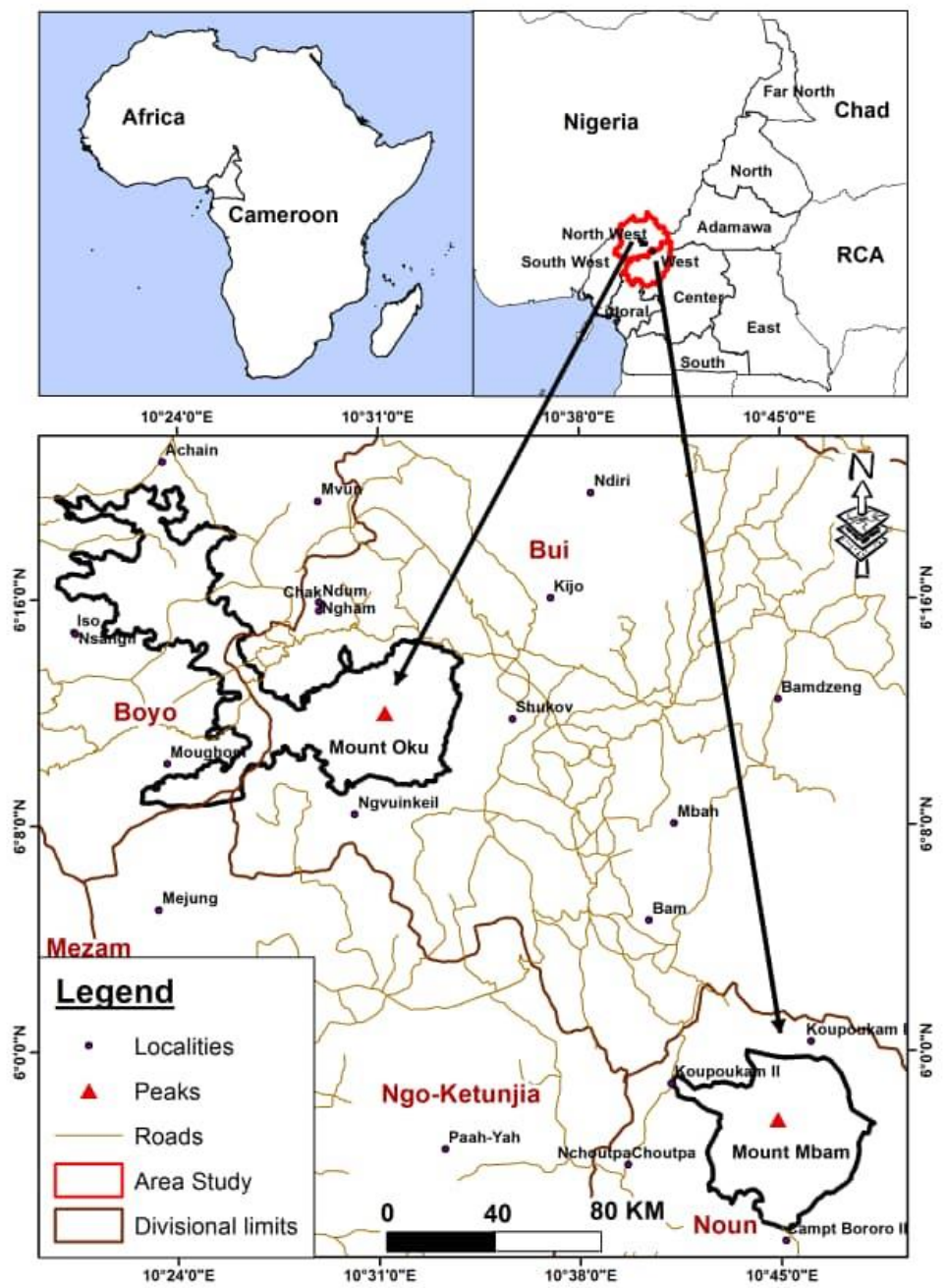

Figure 1: Map showing the location of study sites (Mt Oku and Mt Mbam). 


\section{RESULTS}

\section{Species richness and abundance}

Of the eight species of fruit trees known to serve as food resource to the Bannerman's Turaco, we recorded seven at Mt Oku (Allophylus bullatus, Maesa lanceolata, Prunus africana, Schefflera mannii, Schefflera abysinica, Podocarpus latifolius and Ficus sp.) and five at Mt Mbam (Allophylus bullatus, Prunus africana, Schefflera mannii, Schefflera abysinica, and Ficus sp.). Podocarpus milanjianus was not recorded at either sites while at Mt Mbam, $M$. lanceolata and $P$. latifolius were not observed. A Chi-square test showed no significant difference in species richness between Mt Oku and Mt Mbam (Chisq $=0.333, \mathrm{df}=1$ and $\mathrm{p}=0.5637$ ).

We counted a total of 685 fruit trees, with 531 from Mt Oku and 154 from Mt Mbam (Figure 2). A. bullatus (273 individuals) and $F$. sp (1 individual) were respectively the most abundant and least abundant species at $\mathrm{Mt}$ Oku while at $\mathrm{Mt}$ Mbam, $F . s p(\mathrm{n}=83)$ and $S$. mannii $(\mathrm{n}=1)$ were respectively the most abundant and least abundant species (Figure 2). A Chi-square test at $p<0.05$ showed a significant difference in tree abundance between $\mathrm{Mt} \mathrm{Oku}$ and $\mathrm{Mt}$ Mbam (Chisq $=207.49, \mathrm{df}=1$ and $\mathrm{p}=$ 0.0002). When we controlled for altitude, a similar pattern was observed with fewer abundance of fruit trees (Figure 3). A total of 519 individual fruit trees from both sites, with 402 from Mt Oku and 117 from Mt Mbam
(Figure 3) and a significant difference in tree abundance between the sites (Chisq $=156.5 \mathrm{df}$ $=1$ and $\mathrm{p}=0.0002$ ).

\section{Species diversity and similarity index}

Diversity index for Mt Oku was slightly more than that of Mt Mbam (Table 1) but the difference was not significant (Chisq $=$ 0.0334 , df $=1$ and $\mathrm{p}=0.855$ ) not even after controlling altitude $($ Chisq $=0.1014, \mathrm{df}=1$ and $\mathrm{p}=0.7502$ ).

A similarity index (CC) of 0.79 was obtained between Mt Oku and Mt Mbam for fruit trees known to serve as food resource to Bannerman's Turaco. This means that both sites were $79 \%$ similar in terms of species of fruit trees known to provide food resources to Bannerman's Turaco. Similar results were obtained when we controlled for altitude.

\section{Fruit tree biomass}

Mount Oku with 127,836.01 kg/ha had a significantly higher overall biomass of fruit trees known to provide food resources to Bannerman's Turaco compared with Mt Mbam (84,744.14 kg/ha) $($ Chisq $=5701, \mathrm{df}=$ 1 and $\mathrm{p}=0.0002$ ). Prunus africana in $\mathrm{Mt}$ Mbam had the lowest individual biomass $(50.18 \mathrm{~kg} / \mathrm{ha})$ while Ficus sp. still from Mt Mbam had the highest individual biomass $(75,173.97 \mathrm{~kg} / \mathrm{ha})($ Table 2). A similar pattern was observed when we controlled for altitude and a significant difference observed between sites $($ Chisq $=6602, \mathrm{df}=1$ and $\mathrm{p}=0.0002)$.

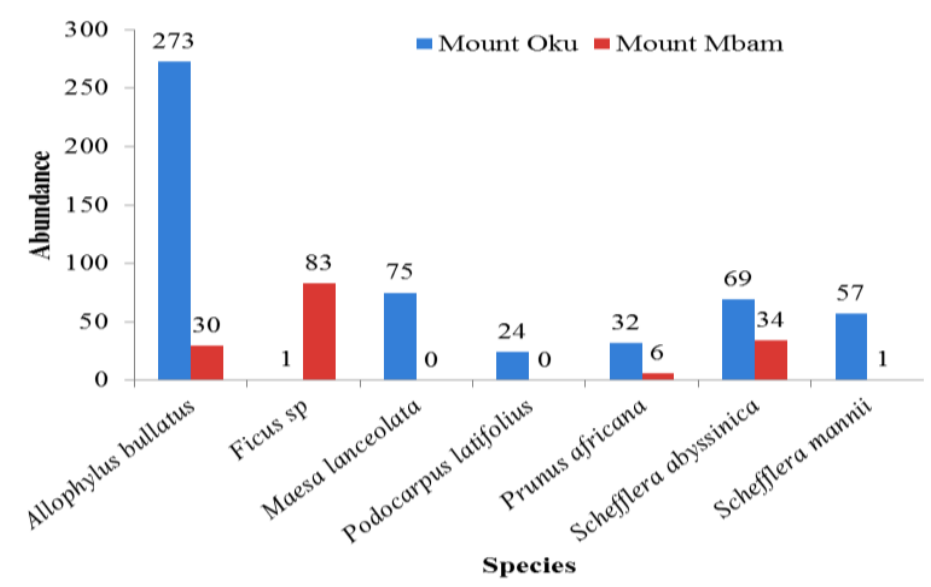

Figure 2: Species abundance of fruit trees providing food resources to Bannerman's Turaco at Mt Oku and Mt Mbam for overall data. 


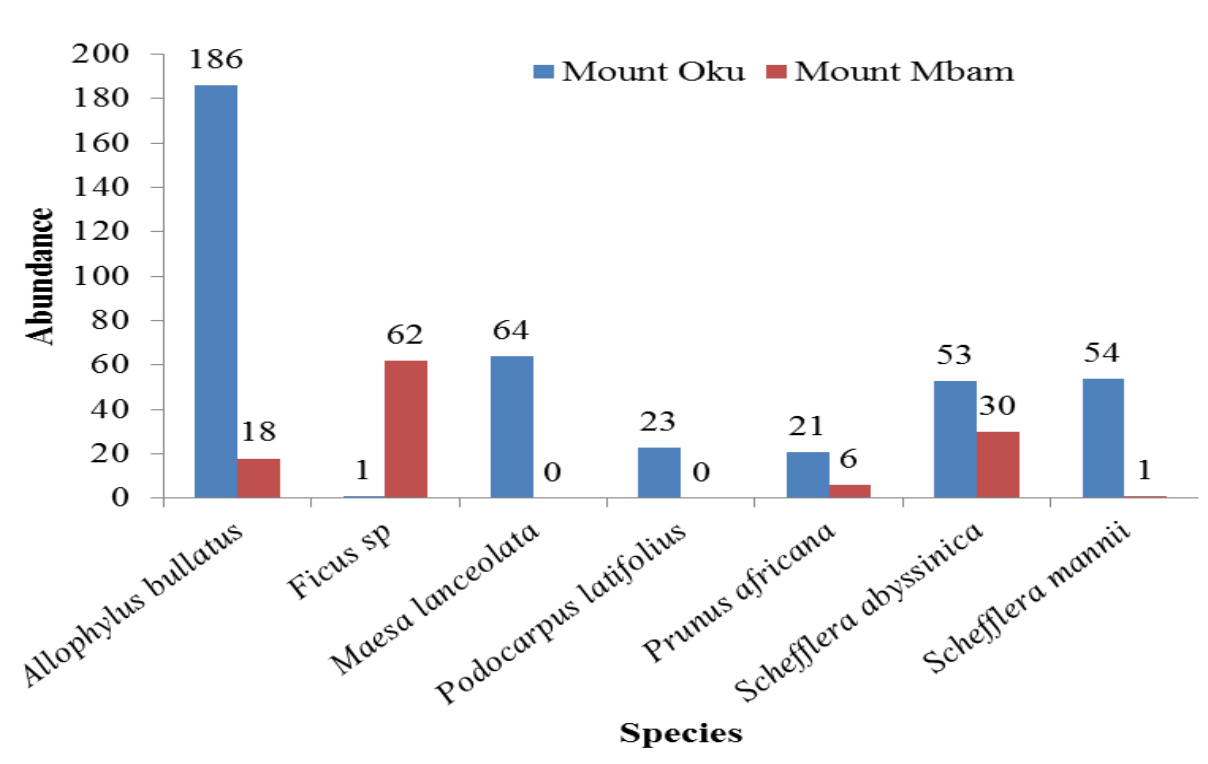

Figure 3: Species abundance of fruit trees providing food resources to Bannerman's Turaco at Mt Oku and Mt Mbam having controlled for altitudes.

Table 1: Species diversity (Shannon index) of fruit trees known to serve as food resources to Bannerman's Turaco at Mt Oku and Mt Mbam for overall data and when controlled for altitude.

\begin{tabular}{ccccc}
\cline { 2 - 5 } & \multicolumn{2}{c}{ Overall data } & \multicolumn{2}{c}{ Controlled } \\
\hline $\begin{array}{c}\text { Diversity } \\
\text { index }\end{array}$ & Mt Oku & Mt Mbam & Mt Oku & Mt Mbam \\
\hline $\begin{array}{c}\text { Shannon } \\
\text { index }\end{array}$ & 1.44 & 1.14 & 1.78 & 1.16 \\
\hline
\end{tabular}

Table 2: Individual biomass $(\mathrm{kg} / \mathrm{ha})$ of fruit trees known to provide food resource to Bannerman's Turaco in Mt Oku and Mt Mbam, based on overall data and when controlled for altitude.

\begin{tabular}{ccccc} 
& \multicolumn{2}{c}{ Overall data (Per ha) } & \multicolumn{2}{c}{ Controlled (Per ha) } \\
\hline Species & Mt Oku & Mt Mbam & Mt Oku & Mt Mbam \\
\hline Allophylus bullatus & $3,385.81$ & 228.37 & $4,014.12$ & 266.54 \\
Ficus sp & $3,467.39$ & $75,173.97$ & $4,334.23$ & $88,935.30$ \\
Maesa lanceolata & $2,110.17$ & $/ *$ & $2,604.79$ & $/ *$ \\
Podocarpus latifolius & $1,049.86$ & $/ *$ & $1,312.32$ & $/ *$ \\
Prunus africana & $3,429.81$ & 50.18 & $4,148.36$ & 64.12 \\
Schefflera abyssinica & $66,556.53$ & $8,635.97$ & $79,375.91$ & $11,034.85$ \\
Schefflera mannii & $47,836.44$ & 655.64 & $59,570.45$ & 837.76 \\
\hline Total & $\mathbf{1 2 7 , 8 3 6 . 0 1}$ & $\mathbf{8 4 , 7 4 4 . 1 4}$ & $\mathbf{1 5 5 , 3 6 0 . 1 8}$ & $\mathbf{1 0 1 , 1 3 8 . 5 7}$ \\
\hline
\end{tabular}

* represent species not recorded in Mt Mbam. 


\section{DISCUSSION}

\section{Species richness and abundance}

The significantly high number of individual fruit trees sampled in Mt Oku ( $\mathrm{n}=$ 531) during this study compared with $\mathrm{Mt}$ Mbam (n = 154) contributes to explain the high population of Bannerman's Turaco at Mt Oku compared with Mt Mbam. The high fruit tree abundance at $\mathrm{Mt} \mathrm{Oku}$ is considered indicative of more food resource availability. This corroborates the works of Reichard et al. (2001); Bobo and Waltert (2011); Liu et al. (2013) who reported that the populations of birds increase in areas with high food abundance. The community management system, currently present at Mt Oku since the year 2000 (Thomas et al., 2000) and which is lacking at Mt Mbam might explain the high fruit tree abundance at $\mathrm{Mt} \mathrm{Oku}$ since the presence of such management systems means that less pressure is exerted on forest resources by the adjacent local communities. In addition, the conversion of forest into new pasturelands at Mt Mbam by the burning of forest, which was observed in our sampled plots in Mt Mbam, but not in Mt Oku, may have substantially reduced the fruit trees there compared with Mt Oku. This concur with Mengesha et al. (2011), who reports the effects of deforestation on cover and food requirements of birds which is reflected on the lower abundances of birds in such areas.

The high population of Bannerman's Turaco at Mt Oku compared with Mt Mbam can also be attributed the overall higher species richness of the fruits trees encountered in Mt Oku, though not significantly different. This concurs with Poulsen (2002) who attributes bird's abundance and species richness to tree age, higher number of tree of various sizes and tree species richness. The overall larger surface area of $\mathrm{Mt} \mathrm{Oku}$ compared with Mt Mbam, with its corresponding larger surface area of suitable montane forest habitats for the Bannerman's Turaco is likely to be responsible for this higher abundance and richness of fruit trees. This corroborates with Kagiampaki et al. (2011), who showed that species richness of vascular plants increased with increase in surface area, known as the Species Area Relationship (SAR). Kallimanis et al. (2010) also demonstrated similar SARs. One remarkable observation was the absence of Podocarpus milanjianus at both sites. This absence may be attributed to high exploitation of timber in the past (Fargon et al., 2013), which probably led to its extirpation in the forest or perhaps the tree did not just occur in our sample plots. However, Thomas (1987) reported it at very high altitudes (above 2600 $\mathrm{m})$ but our local field guide who was quite experienced indicated the tree does not occur in the forest. We recorded one individual of the tree species in the village at the foot of Mt Oku along the roadside. It is also possible that the tree used to be present and served as food to Bannerman's Turaco at low altitudes of the forest, but the conversion of these areas into farmlands led to its disappearance at lower altitudes. About the absence of Podocarpus latifolius and Maesa lanceolata at Mt Mbam, it could be that the trees were over exploited in the past leading to its disappearance in the area or they simply had never occurred in the area, since we did not come across any literature that mentioned these species in Mt Mbam.

\section{Species diversity and similarity index}

Species diversity of fruit trees was higher in Mt Oku compared with Mt Mbam. Even though the difference is not significant, it can be a contributing factor to the high Bannerman's Turaco population at Mt Oku. According to Kissling et al. (2007), bird abundances are likely to be greater in places of high plant diversity, if plant species richness leads to increase in total abundance of fruit resources.

The 0.79 similarity index of fruit tress between both sites might justify why both sites are strongholds for Bannerman's Turaco within the Bamenda highlands. The geographic proximity and the fact that both sites likely face similar climatic conditions (given that both sites occur within the Western highlands of Cameroon and are both montane forest) might explain the $79 \%$ similarity between both sites. Genet and Ejigu (2017) 
showed that sites facing similar climatic conditions are likely to have a high similarity index.

\section{Fruit tree biomass}

A significantly higher fruit tree biomass was recorded in Mt Oku compared with Mt Mbam and could contribute to explain the high population of Bannerman's Turaco in Mt Oku. Tree DBH that is a measure tree biomass is assumed by many researchers to reflect a tree's ability to produce fruits, whereby higher tree biomass implies more fruit production and hence more available food resource to the bird (Leighton and Leighton, 1982; Chapman, 1989; Chapman, 1990). The high fruit tree biomass at Mt Oku compared with Mt Mbam, could be attributed to the higher abundance of fruit trees encountered there. The overall high fruit tree species diversity at Mt Oku compared with Mt Mbam could also contribute to its high fruit tree biomass, which corroborates Cardinale et al., (2007) that higher plant diversity leads to higher plant biomass.

\section{Conclusion}

Species richness and diversity of fruit trees providing food resources to Bannerman's Turaco though higher in Mount Oku did not vary significantly compared with Mt Mbam. However, the abundance and biomass of fruit trees was significantly higher in Mt Oku, suggesting that Mt Oku has a higher food resource availability which contributes to explain the higher abundance of Bannerman's Turaco in Mt Oku. The high similarity index between both sites explains why Mt Mbam is equally a stronghold for Bannerman's Turaco within the western highlands of Cameroon. Hence, conservation efforts to protect this endangered Bannerman's Turaco should take into consideration the protection of fruit trees on which it feeds.

\section{COMPETING INTERESTS}

The authors declare that they have no competing interest.

\section{AUTHORS' CONTRIBUTIONS}

TAII conceived and designed the study/analysis and helped to draft the manuscript. NVKT collected the data, performed the statistical analysis and drafted the manuscript. Both of us read and approved the final manuscript.

\section{ACKNOWLEDGMENTS}

We thank the local communities around Mt Oku and Mt Mbam for allowing us to work at these sites. We express our gratitude to Herve Dikongue who aided with the logistic before the start of fieldwork. We equally thank Elie Kamdoum, the botanist who helped with tree identification. We are grateful to our local field guides George Foncha and Keran Sedvizem for their remarkable assistance during fieldwork at $\mathrm{Mt}$ Oku and Mt Mbam respectively.

\section{REFERENCES}

Asanga C. 2002. Case study of exemplary forest management in Central Africa: community forest management at the Kilum-Ijim Mountain forest region Cameroon. Conservation and sustainable management of tropical moist forest ecosystems in Central Africa, forest management Working Papers, Working Paper FM/11. Forest Resources Development Service, Forest Resources Division, FAO, Rome-Italy.

Bascompte J, Jordano P. 2007. Plant-animal mutualistic networks: the architecture of biodiversity. Annual Review Ecology Evolution and Systematics, 38: 567-593. DOI:10.1146/annurev.ecolsys.38.091206 .095818

Birdlife International. 2017. Species factsheet: Tauraco bannermani. Birdlife International. http:// www.birdlife.org.

Bobo KS, Waltert M. 2011. The importance of agricultural areas for bird conservation in the Korup region, southwestern Cameroon. Int. J. Biol. Chem. $\begin{array}{lll}\text { Sci., } & \text { 5(2): 419-432. }\end{array}$ http://ajol.info/index.php/ijbcs.

Cardinale BJ, Wright JP, Cadotte MW, Carroll IT, Hector A, Srivastava DS, 
Loreau M, Weis JJ. 2007. Impacts of plant diversity on biomass production increase through time because of species complementarity. Proc. Natl. Acad. Sci., 104(46): 18123-18128. DOI: 10.1073/pnas.0709069104

Chapman CA. 1989. Ecological constraints on group size in three species of neotropical primate. Folia Primatologica, 55: 1-9. DOI: $10.1159 / 000156492$

Chapman CA, Chapman LJ, Wangham R, Hunt K, Gebo D, Gardner L. 1992. Estimators of fruit abundance of tropical trees. Biotropica, 24(4): 527-531. DOI: $10.2307 / 2389015$

Chapman CA. 1990. Association patterns of male and female spider monkeys: the influence ecology and sex on social organization. Behav. Ecol. Sociobiol., 26(6): 409-414. DOI: https://doi.org/10.1007/BF00170898.

Cunningham AB, Mbenkum FT. 1993. Sustainability of harvesting Prunus africana bark in Cameroon: a medicinal plant in international trade. People and Plants Working Paper 2. UNESCO Press, Paris.

Djomo AN, Adamou I, Joachim S, Gode G. 2010. Allometric equations for biomass estimations in Cameroon and pan moist tropical equations including biomass data from Africa. Forest Ecology and Management, 260(10): 1873-1885. DOI: 10.1016/j.foreco. 2010.08.034

Dowsett-Lemaire F, Dowsett R. 1993. Comments on the taxonomy of some afrotropical bird species. Tauraco Research Report, 5: 323-389.

Fargon A, Foden W, Potter L. 2013. Podocarpus latifolius. The IUCN red list of threatened species 2013.

Farjon A. 2013. Podocarpus milanjianus. The IUCN red list of threatened species.

Field R, O'Brien EM, Whittaker RJ. 2005. Global models for predicting woody plant species richness from climate: development and evaluation. Ecology, 86(9): 2263-2277. DOI: https://doi.org/10.1890/04-1910
Fishpool LDC, Evans MI. 2001. Important Bird Areas in Africa and Associated Islands. Priority Sites for Conservation: Birdlife Conservation Series No. 11. Pisces Publications and Birdlife International: Newbury and Cambridge.

Fleming TH, Ranta E. 2005. The relationship between species richness of vertebrate mutualists and their food plants in tropical and subtropical communities differs among hemispheres. Oikos., 111(3): 556-562. DOI: https://doi.org/10/1111/j.16000706.2005.14272.x

Forboseh PF, Ikfuingei RN. 2001. Estimating the population densities of Tauraco bannermani in the Kilum-Ijim forest, Northwestern Cameroon. Ostrich Supplement, 15: 114-118.

Fotso RC, Dowsett-Lemaire F, Dowsett RI, Cameroon Ornithological Club, Scholte P, Languy M, Bowden C. 2001. Cameroon. In Important Birds Areas of Africa and Associated Islands: Priority sites for Conservation, Fishpool LDC, Evans MI (Eds.). Pisces Publication and Birdlife International: Newbury and Cambridge; 133-159.

Fry CH, Keith S, Urban EK. 1988. The Birds of Africa (vol. 3). Academic Press: London.

Garcia D, Zamora R, Amico AGC. 2009. Birds as suppliers of seed dispersal in temperate ecosystems: Conservation guidelines from real-world landscapes. Conservation Biology, 24(4): 1070-1079. DOI: $10.1111 / \mathrm{j} .1523-1739.2009 .01440 . \mathrm{x}$

Genet Y, Ejigu DB. 2017. Community composition, relative abundance and habitat association of avian species in Apini and Dikuma forest patches, Awi administrative zone, Ethiopia. Ethiop. J. Sci. \& Technol., 10(1) 33-50. DOI: 10.4314/ejst.v10i1.3

Gregory RD, Willis SG, Jiguet F, Vorisek P, Klanova A, van Strien A. 2009. An indicator of the impact of climatic change of European bird populations. PlosOne, 4(3): e4678. DOI: 10.1371/journal.pone.0004678 
Hawkins BA, Field R, Cornell HV, Currie DJ. 2003. Energy, water, and broad-scale geographic patterns of species richness. Ecology, 84(12): 3105-3117. DOI: https://doi.org/10.1890/03-8006

Jarvis MJF, Currie MH. 1978. Breeding of captive knysna and purple crested louries. Ostrich., 50: 38-44.

Joppa LN, Roberts DL, Myers N, Pimm SL. 2011. Biodiversity hotspots house most undiscovered plant species. Proc Natl Acad Sci., 108(32): 13171-13176. DOI:

10.1073/pnas.1109389108

Kagiampaki A, Triantis K, Vardinoyannis K, Mylonas M. 2011. Factors affecting plant species richness and endemism in the South Aegean (Greece). Journal of Biological Research-Thessaloniki, 16: 282-295.

Kallimanis AS, Bergmeier E, Panitsa M, Georghiou K, Delipetrou P, Dimopoulos P. 2010. Biogeographical determinants for total and endemic species richness in a continental archipelago. Biodiversity and Conservation, 19(5): 1225-1235.

Kissling DW, Rahbek C, Bo"Hning-Gaese K. 2007. Food plant diversity as broad-scale determinant of avian frugivore richness. Proc. R. Soc., 274(1611): 799-808. DOI: 10.1098/rspb.2006.0311

Konan EM, Yaokokore-Beibro KH. 2015. Variation temporelle $\mathrm{du}$ peuplement aviaire des écosystèmes lacustres de la ville de Yamoussokro, centre de la Côte d'Ivoire. Int. J. Biol. Chem. Sci., 9(6): 2566-2581.

DOI: http://dx.doi.org/10.4314/ijbcs.v9i6.5

Kottek M, Grieser J, Beck C, Rudolf B, Rubel F. 2006. World map of Koppen-Geiger climate classification updated. World Map of Köppen-Geiger Climate Classification updated. Meteorol. Z., 15(3): 259-263. DOI: 10.1127/09412948/2006/0130

Leighton M, Leighton DR. 1982. The relationship of size and feeding aggregate to food patch: Howler monkey Alouatta palliata feeding in Trichilia cipo trees on Barro Colorado Island. Biotropica, 14: 81-90.
Liu Y, Webber S, Bowgen K, Schmaltz L, Bradley K, Halvarsson P, Abdelgadir M, Griesser M. 2013. Environmental factors influence both abundance and genetic diversity in a widespread bird species. Ecol Evol., 3(14): 4683-4695. DOI: 10.5061/dryad.n837

Mckay CR. 1994. Survey of Important Bird Areas for Bannerman's Turaco Tauraco Bannermani and Banded Wattle-Eye Platysteira Latincincta in North-West Cameroon. Birdlife International (Unpubl. Report).

Mckay CR, Coulthard N. 1996. The KilumIjim Forests IBA in Cameroon: monitoring biodiversity using birds as indicators. Poster presented at the IX Pan African Ornithological Congress, Accra, Ghana, 1-7 December.

Mengesha G, Mamo Y, Bekele A. 2011. A comparison of terrestrial bird community structure in the undisturbed and disturbed areas of the Abijata Shalla lakes National Park, Ethiopia. International Journal of Biodiversity and Conservation, 3(9): 389-404.

Moran C, Catterall CP, Green R, Olsen MF. 2005. Functional variation among frugivorous birds: Implications for rainforest seed dispersal in a fragmented subtropical landscape. Oecologia., 141(4): 584-595. DOI: 10.1007/s00442004-1685-1

Ngute ASK, Hulme M, Whytock RC, Taku A, Mayaka TB. 2019. The avifauna of Mount Mbam, Cameroon. Bull $A B C$, 26(1): 82-91.

Nirmala T. 2016. Food availability influences the seasonality of bird community in tropical forest. Western Ghats. Int. J. Curr. Res. Rev., 8(2): 74-83.

Njabo YK. 2003. Analyses of endangered birds of the Cameroon Highlands. Field report.

Njabo YK, Languy M. 2000 Surveys of selected montane and submontane forests in the Bamenda Highlands in March 2000. Unpublished.

Poulsen BO. 2002. Avian richness and abundance in temperate Danish forest: 
tree variables important to birds and their

conservation. Biodiversity and

Conservation, 11(9): 1551-1566. DOI: https://doi.org/10.1023/A:101683951817 2

Rahbek C. 2005. The role of spatial scale and the perception of large scale species richness patterns. Ecological letters, 8(2): 224-239. DOI: https://doi.org/10.1111/j.14610248.2004.00701.x

Reichard SH, Chalker-Scott L, Buchanan S. 2001. Interactions among non-native plants and birds. In Avian Ecology and Conservation in an Urbanizing World, Marzluff JM, Bowman R, Donnelly R. (Eds.). Kluwer Academic Publishers: Boston; 179-223.

Sanaei A, Chahouki M, Ali A, Jafari M, Azarnivand H. 2017. Abiotic and biotic drivers of aboveground biomass in semi steppe rangelands. Sci Total Environ., 15(615): 895-905. DOI: 10.1016/j.scitotenv.2017.10.010

Stuart SN. 1986. Conservation of Cameroon montane forests. International Council for Bird Preservation: Cambridge, U.K.

Thomas DHL, Anders S, Penn NJ. 2000. Conservation in the community: the Kilum-Ijim Forest Project, Cameroon.
Ostrich, 71(1-2): 157-161. DOI: 10.1080/00306525.2000.9639898

Thomas DW. 1987. Vegetation of Mount Oku. In The Conservation of Oku Mountain Forest, Cameroon, Macleod HM (ed.). International Council for Bird Preservation: Cambridge, UK.

Tye H. 1986. The climate of the Highlands of Western Cameroon. In Conservation of Cameroon Montane Forest, Stuart SN. (ed). International Council for Bird Preservation: Cambridge; 18-19.

Walther GR, Post E, Convey P, Menzel A, Parmesan C, Beebe TJ, Fromentin JM, Hoegh-Guldberg O, Bairlein F. 2002. Ecological responses to recent climate change. Nature, 416(6879): 389-395. DOI: $10.1038 / 416389$ a

Williams SE, Middleton J. 2007. Climatic seasonality, resource bottlenecks, and abundance of rainforest birds: implications for global climate change. Divers. Distrib., 14(1): 69-77. DOI: https://doi.org/10.1111/j.14724642.2007.00418.x 